\title{
Maury for Modern Times NAVIGATING A RACIST LEGACY IN OCEAN SCIENCE
}

\author{
By Penelope K. Hardy and Helen M. Rozwadowski
}

ABSTRACT. Amid recent calls in the United States and elsewhere to remove statues and other references that glorify historically racist figures, we offer a reexamination of nineteenth-century naval officer and early ocean scientist Matthew Fontaine Maury. While Maury made significant contributions toward understanding and representing the ocean-atmosphere system and argued for increased support from both government and the public for such studies, his work, including his science, was also inextricably involved in his nation's imperialist goals. Before and after his resignation from the United States Navy to join the Confederacy during the American Civil War, Maury worked for the perpetuation and expansion of race-based slavery. For these reasons, we argue that oceanographers, historians, and the public need to rethink depictions of Maury that glorify his accomplishments without interrogating their darker side. Presenting honest portrayals is not only historically responsible but also aids the larger endeavor to recruit and retain more diverse students and scientists for ocean science.

\section{INTRODUCTION}

In the wake of George Floyd's death at the hands of Minneapolis police officers in late May 2020, people around the United States and elsewhere launched protests to call attention to the mistreatment of African Americans and other people of color. Protesters quickly expanded their goals to include removal of statues of prominent figures whose actions explicitly or implicitly supported the systemic racism that led to the current crisis, beginning with the long history of slavery with which the United States has insufficiently reckoned. Confederate politicians and military leaders bore the first brunt of this attack, with calls across the country to remove their statues and their names from buildings.

Among numerous statues targeted, one of Matthew Fontaine Maury in Richmond, Virginia, initially inspired only the vague graffiti condemnation, "F** this guy too" (Figure 1). Maury, familiar to many in the ocean science and maritime communities as the "father of oceanography" and "pathfinder of the seas," is clearly less well known outside of specialist circles. Yet all who recognize Maury's contributions to science, navigation, and naval reform must widen their vision of his legacy to understand and acknowledge its darker implications.

A Virginian transplanted at a young age to Tennessee, Maury joined the navy after hearing an older brother's sea stories. Always concerned about the lack of formal education for naval officers, Maury turned to science as a career path after a leg injury ended his hopes of command at sea. As head of the Depot of Charts and Instruments and superintendent of the new Naval Observatory, Maury applied navy resources to the development of science, particularly astronomy and hydrography. He was an early leader in the organization of meteorology and ocean science on the national and international levels. His efforts resulted in an expansive series of charts that not only shortened

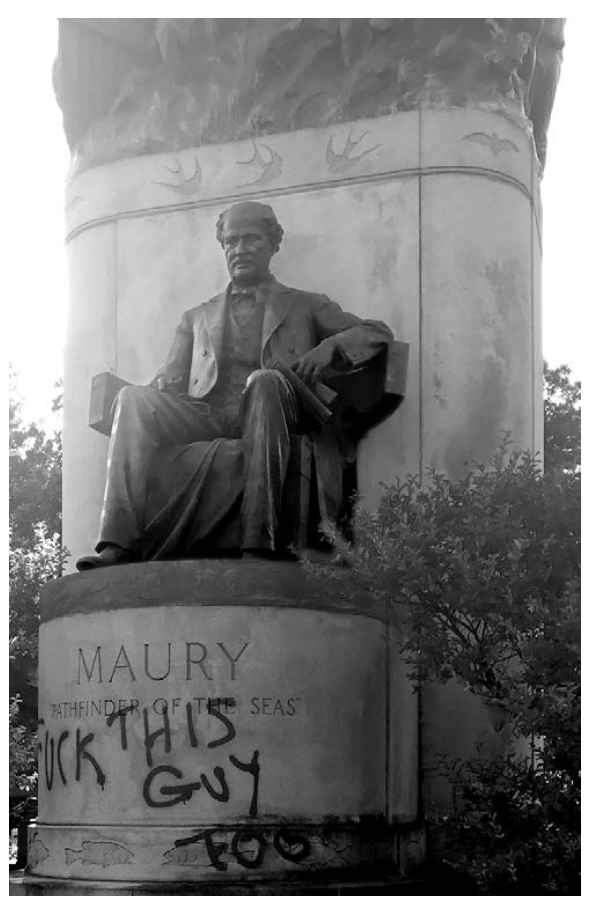

FIGURE 1. A statue of Matthew Fontaine Maury on Monument Avenue in Richmond, Virginia, was graffitied in mid-June 2020. Photo credit: Adam H. Domby

routes for mariners but also represented winds, currents, depths, temperatures, and even biological information in synoptic format. His book The Physical Geography of the Sea remained in print for decades, through numerous editions. His US navy career came to an end in 1861, when he resigned his commission at the start of the American Civil War to join the Confederate navy (Grady, 2015).

This latter service led to the installation of the Richmond monument in 1929, one of five statues honoring Confederates. Of this group, Maury was the only one who was not a general or president and the 
only one whose monument celebrated his pre-Confederacy scientific contributions rather than his wartime service (Springston, 2019). On June 10, 2020, the nearby statue of Confederate president Jefferson Davis was torn down by protesters, and various levels of government began discussing the disposition of the others (Joachim and Alonso, 2020). Richmond's mayor invoked emergency powers to remove the statue of Stonewall Jackson on July 1 (Cole and Duster, 2020). By July 2, Maury, too, was gone (Manzanares, 2020).

Those most familiar with Maury as a founding figure in oceanography might assume he is being criticized unfairly, based on his proximity to his statuary neighbors. However, Maury's links with the Confederacy's central commitment to the enslavement of African Americans are not mere guilt by association. The ongoing protests make now an appropriate moment for ocean scientists, both in the United States and elsewhere, to take a closer look at Maury's tangled scientific and ideological legacies, both because his ideology profoundly shaped his science and because his widely acknowledged role in early oceanography has implications for efforts by the oceanographic community to demonstrate its commitment to inclusion and anti-racism.

\section{MAURY AND MEMORY}

As with all historical figures, assessments of Maury's life and work reflect the concerns and preoccupations of the eras in which they were written. During his lifetime, Maury's reputation suffered when he departed Washington because his absence left Alexander Dallas Bache, head of the US Coast Survey and Maury's rival for cartographic resources, free to denigrate his contributions (Slotten, 1994; Manning, 1998). After Maury's death in 1873, his children initiated his rehabilitation, beginning with a hagiographic biography by his daughter Diana Fontaine Maury Corbin (1888).

Corbin's effort to shape her father's memory reflected a wider effort by
Southerners to both make sense of the experience of the war and redefine themselves as Americans (Blight, 2001). Southerners, and especially Southern women like Corbin, actively sought to commemorate their parents' lives and assign them a noble purpose to lift the shadow of a failed war (Cox, 2019). Their efforts were a subset of Progressive Era projects to beautify public spaces, support education, and provide care for the poor, but Southerners used such projects to recast the Southern war effort as just and heroic while downplaying the role of slavery as a casus belli and celebrating the system of white supremacy that had provoked-and outlived-the conflict. White Northerners proved remarkably sympathetic to this reframing of the war, which became known as the "Lost Cause," both to promote reintegration of former Confederate states into the Union and equally to maintain white supremacy (Blight, 2001).

Maury, in this moment, proved a remarkably useful figure. His efforts during the war-to develop electrically actuated floating mines and to acquire British ships to raid American merchant shipping-were little remembered, whether because they largely occurred abroad or because they were mostly ineffective. He was thus easy to rehabilitate with a Lost Cause reinterpretation of his resignation as a courageous and honorable act of conscience. The damage his actions did to American merchant shipping was conveniently forgotten. Instead, Corbin and others after her focused on Maury's ocean science, its contributions to America's reputation in Europe, and especially its international nature.

Citizens in Richmond began a campaign to memorialize Maury, with funding from private individuals, the city's business community, and the state (Hall, 1929). A flurry of biographies appeared in the years immediately surrounding the statue's installation. Both books and statue focused on Maury's contributions to navigation and science (Lewis, 1927; Caskie, 1928; Wayland, 1930).
Celebrating his scientific contributions supported Lost Cause ideology by eliding his role in the Confederacy and support for the institution of slavery. The dishonest and damaging reinterpretation of history presented in the monument also buttressed white supremacy and segregation (Barbee, 2012; Domby, 2020).

Maury's successful rehabilitation was also solidified into architecture, particularly that associated with education. Maryland, home state of the US Naval Academy (USNA), had been on the border during the Civil War and, in the throes of the Lost Cause ideology's success, an academic building at USNA was named for Maury (Hall, 1929; Figure 2). Honoring a former Confederate officer at the place where future American naval officers are trained symbolically welcomed him back into the fold. Recognizing Maury alongside other naval heroes on campus presented him as a role model for the midshipmen who would go on to lead future sailors and marines, especially as the twentieth century navy required an increasingly technical education. Maury's name also adorns other educationrelated buildings, including one at Fort Trumbull, in New London, Connecticut, used to train US Maritime Service officers during World War II; a hall at James Madison University, in Harrisonburg, Virginia; and a high school in the erstwhile Confederate port of Norfolk, Virginia, among others (WHSV, 2020; Gregory, 2020).

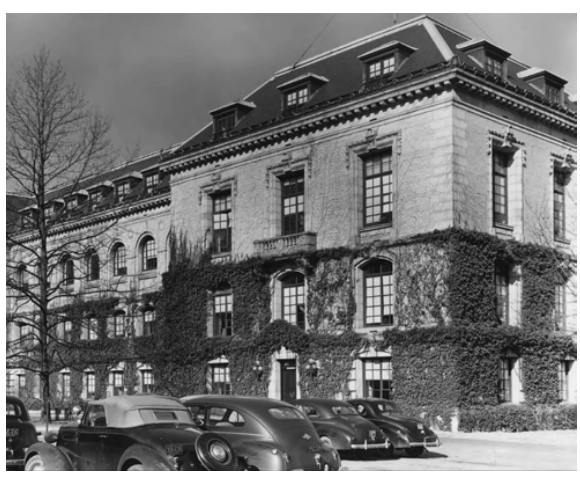

FIGURE 2. Maury Hall is located at the United States Naval Academy. The picture was taken on December 15, 1944. US Navy file photo 


\section{PATHFINDER OF THE SEA}

Maury became important to oceanographers, and particularly to Americans, for a variety of reasons (Figure 3). In Great Britain, interest in oceanography's roots found a natural focus in the 1870 s HMS Challenger voyage; indeed, the voluminous published results brought the word "oceanography" into mainstream use. Americans, though, sought their own story, and they found it in Maury. He was among the first to systematically collect and compare things like temperature and current information on a near-global scale. He "envisioned an all-encompassing study of the oceans and atmosphere, from every angle and at every depth, to discover every physical law," making him a role model for those still striving to carry out his charge (Hardy, 2016a, p. 44). The 1859 edition of his Physical Geography of the Sea had even marked the very first use of the English word "oceanography" (Oceanography, n.d.). That meant, to the satisfaction of Americans looking for a national symbol, he conveniently beat British scientists to the word by 20 years. Who better, then, to credit with the paternity of the discipline?

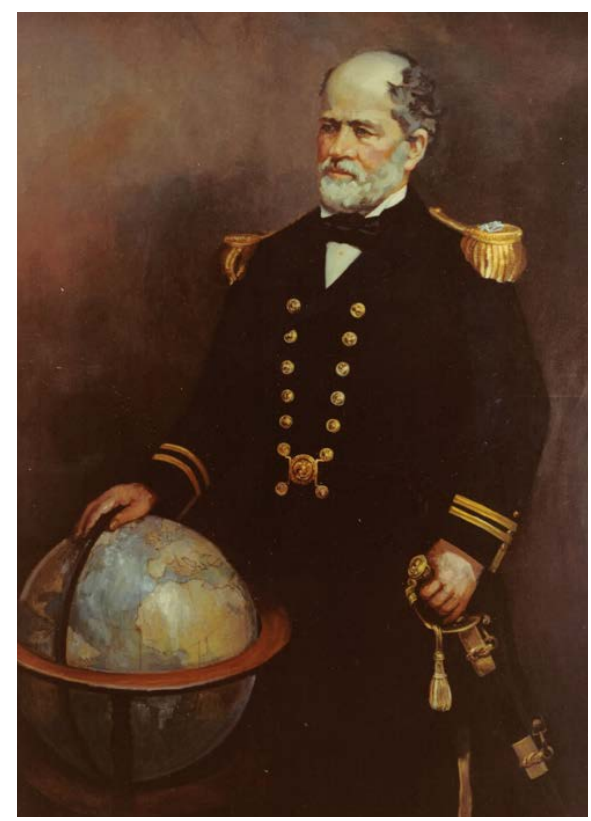

FIGURE 3. Commander Matthew Fontaine Maury was captured in full navy regalia by artist E. Sophonisba Hergesheimer. US Navy file photo
Oceanographers incorporated this history into the teaching of the science itself, so that many students learned, and continue to learn, the stories of how various ocean processes came to be understood alongside the science and mathematics of the processes themselves. These lessons understandably invite a historical component; expressing volume transport in Sverdrups, for instance, makes more sense if one knows something about Harald Sverdrup's work. Typical modern ocean and marine science textbooks include an entire chapter on the history of the field, in striking contrast to textbooks of biology, chemistry, genetics, and other fields which do not (see, for example, Stewart, 2008; Sverdrup et al., 2008; Garrison and Ellis, 2015). In today's textbooks, Maury is celebrated as "the first true oceanographer" (Sverdrup et al., 2008, p. 12) and "perhaps the first person for whom oceanography was a full time occupation" (Garrison and Ellis, 2015, p. 43). Having identified Maury as sharing their desire to explain the oceanatmosphere system, oceanographers-as naval officers before them-also found in him a role model for young scientists, and knowing his personal story of struggle and success only made this a better fit. Maury spent much of his navy career fighting for financial and political sup- port for his projects; trying to convince the public, the navy, and the Congress of the importance of his work; and calling for international scientific cooperation. It is not a stretch for today's oceanographers to imagine themselves in Maury's shoes.

Beyond textbooks, Maury's name has been assigned to facilities bridging navy and oceanographic purposes. The Naval Oceanographic Office Library traces its origins to an 1871 order for the Naval Hydrographic Office-a successor of Maury's Depot of Charts and Instruments-to collect and catalog hydrographic reference works; in 1986, the library found its current home at Stennis Space Center in Mississippi, and was named for Maury (Lammons, n.d.). The Woods Hole Oceanographic Institution campus has a Maury Lane. In 2016, the US Navy christened the USNS Maury, a Pathfinder class oceanographic survey ship designed for acoustic, biological, physical, and geophysical surveys at sea and for the operation of autonomous underwater vehicles (Figure 4).

In the 1960s and 1970s, scholarly works by historians, geographers, and oceanographers began to critique the content of Maury's theories of oceanic movements, as, indeed, his contemporaries also had, and judged Maury himself more a technician or data compiler

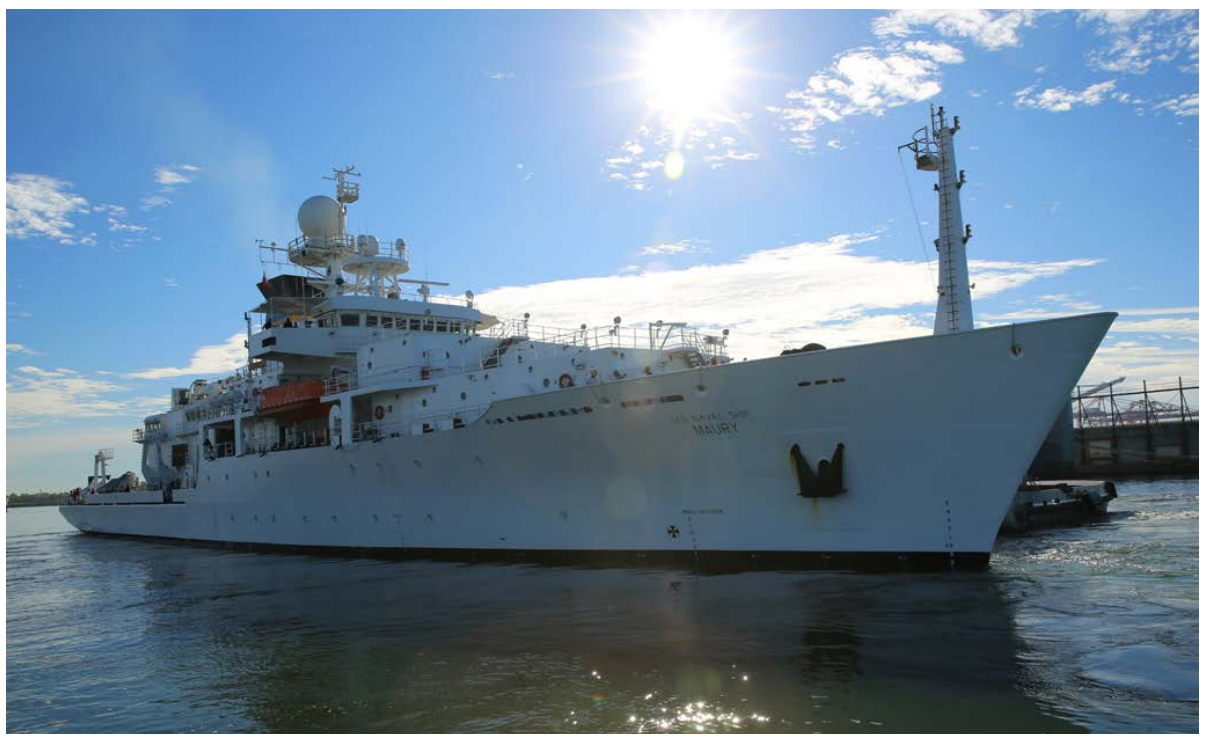

FIGURE 4. Military Sealift Command's oceanographic survey ship USNS Maury pulls into Naval Station Norfolk, Virginia, in November 2017. US Navy photo by Bill Mesta 
than a scientist (Leighly, 1963; Stommel, 1965; Reingold, 1964; Deacon, 1997). However, more recent scholarship presents a more nuanced view; although his ocean circulation model may be wrong, historians today recognize that Maury's practice of science was "in fact, typical, and representative, of his time and his location in Washington, DC" (Hardy, 2016b, p. 404). His powerful visual representations of oceanic phenomena (such as his wind and current charts and whale charts) attracted international attention and enabled mariners to navigate more swiftly and safely (Dick, 2003; Burnett, 2005; Rozwadowski, 2005; Achbari, 2015; Smith, 2018). He was also responsible for the first ocean-basin scale bathymetric chart, included in the fifth edition of his Sailing Directions (1853, Plate XIV), and the first sediment samples from the Atlantic seafloor (Rozwadowski, 2005; Hardy, 2016a). Historians also recognize that Maury's scientific and naval work supported American expansionism. In this, Maury contributed to the long-standing effort to employ science in the service of empire, a strategy widely recognized by historians of ocean science (Reidy and Rozwadowski, 2014; Smith, 2018).

\section{MAURY THE CONFEDERATE}

Apologists for Maury might point out that, although a Southerner who resigned his naval commission to support the Confederacy, he did not own slaves himself. While true, this ignores the vigorous and consistent efforts he made to support and extend the institution of slavery. From the 1830s, he wrote a series of influential articles advocating assertive American military policy rooted in his proslavery beliefs (Karp, 2011, 2016; Johnson, 2013). By the 1850s, he was pursuing a concerted program of publication and lobbying to encourage US exploration in South America with the design of expanding the American system of racial slavery to that region and with the hope of resolving political tensions building between the North and South over the issue of slavery's expansion within the United States (Verney, 2020).

Maury's efforts to expand the slave nation outlasted his service in the US Navy. His war-era work in Britain as a Confederate government agent so angered the American merchant mariners who had provided data for his wind and current charts that the Salem [Massachusetts] Marine Society turned its portrait of him upside down and around to face the wall (Grady, 2015; Figure 5). As the war ended in Southern defeat, Maury feared arrest for treason if he returned to the United States, so he switched flags again, working in the service of Maximilian I of Mexico to establish a "New Virginia" in Mexico, arranging customs waivers, tax exemptions, and land grants to entice Southerners to move and take their enslaved laborers with them (Majewski and Wahlstrom, 2012; Wahlstrom, 2015). Maury was so unwilling to let slavery go that friends found it hard to convince him emancipation was already a fact, and formerly enslaved Americans would not willingly move to Mexico to perpetuate their bondage. Maury returned to the United States only in 1868, after Maximilian's regime collapsed and after enough other Confederate officers received paroles for their treason that he felt safe to do so (Majewski and Wahlstrom, 2012).

Despite support of slavery by many of Maury's background and social class, arguments against slavery existed from early in American history, and they were gaining tremendous traction during his time (Varon, 2010). Even some among Maury's own large but tightly knit Southern family recognized slavery as a moral wrong. In January 1851, Maury's Virginia cousin Mary B. Blackford wrote to him about his proposal to bring American slavery to Brazil, declaring, "my heart sickened, yes! If a heart could bleed, mine did when I thought that one so near me had proposed this mighty

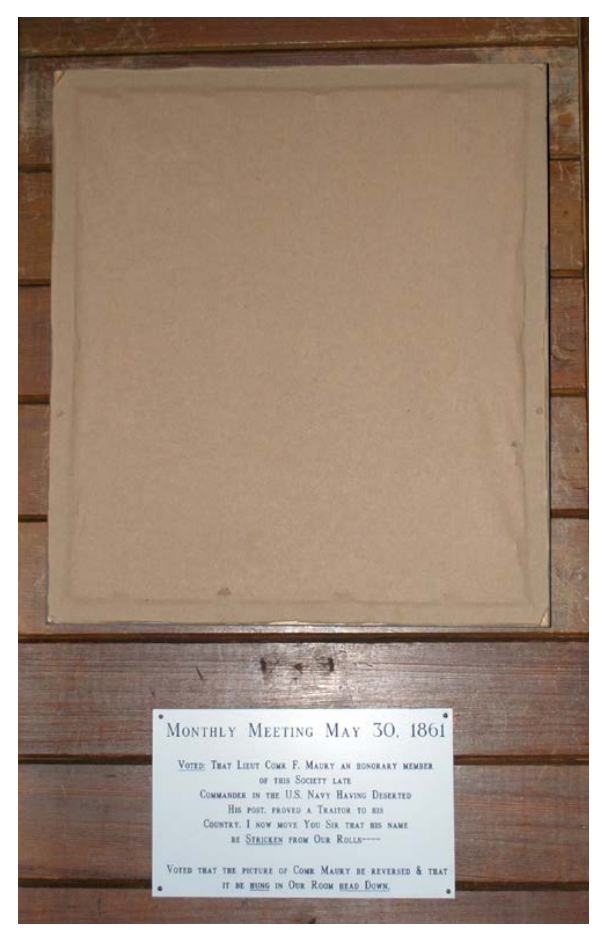

FIGURE 5. During the American Civil War, the Salem Marine Society flipped Maury's portrait upside and toward the wall. According to Allan Vaughan, current secretary of the society, a replica remains in the reversed position (personal communication, July 4, 2020). Photo credit: Linda Orlomoski

wrong." Blackford urged him to use his influence to support abolition. He ignored her advice, instead working for the next 17 years to perpetuate and export racial slavery. This puts him beyond even the common racism of his time, because he not only believed in the slave system, but acted aggressively in its support and wrote virulently about white supremacy.

This goal of extending the slave system thus was neither a brief blip in a career otherwise dedicated to science, nor separate from that science itself. Maury's scientific efforts, though international in their aims, were always intended to further the commercial agenda of the United States as a global imperial power. While conducting science in the national interest is not unusual, in Maury's case that mission included human bondage. To remember Maury's science without accounting for its shadows presents a misleading and revisionist version of his history. 


\section{CONCLUSION}

What, then, ought ocean scientists and their historians, among others, do with this newfound awakening to Maury's dual admirable and reprehensible legacies? Monuments, which reflect the values of their creators and time, "have an expiration date" and offensive ones should be removed or repurposed to teach something about the moment of their creation (Marcus and Woodward, 2020). While the Richmond statue of Maury is gone, other memorials to him remain under discussion (Gregory, 2020; WHSV, 2020; Witte, 2020). Some commentators, assuming science to be neutral, make a distinction between the treasonous activities of the Confederacy and memorialization of Maury's earlier contributions (Donegan, 2020; Witte, 2020). That distinction is offered in defense of retaining the name "Maury Hall" for the building at USNA, or for renaming it "Lt. Maury Hall" to clarify the intent to memorialize his pre-war scientific work (Donegan, 2020). However, historians have long recognized that science is never neutral; recently, science historian Naomi Oreskes used ocean science as a case study to show how apparently objective science in fact reflects the goals and priorities of both scientists and their patrons (Oreskes, 2020).

In contemplating what to do with things that celebrate Maury or his science, we might reflect on the reasons institutions and individuals look to history. According to historian Margaret Deacon (1997), there was growing interest among oceanographers in the middle of the twentieth century to demonstrate that oceanography, considered a new field after World War II, "in fact had a history as long and distinguished as other sciences" (p. xxvii). Role models are important for recruiting newcomers to a field; indeed, the pressing need to recruit oceanographers during the massive Cold War expansion of the field largely explains the popularity then of histories focused on individual scientists. The study questions in one oceanography textbook include, "Who was Maury and why was he considered by many to be the founder of oceanography?"; the review materials for this chapter only identified four other figures by name: James Cook, Benjamin Franklin, Edwards Forbes, and Fridtjof Nansen (Sverdrup and Armbrust, 2008, p. 25). It is worth asking, what is the message conveyed by elevating Maury among other historical figures in oceanography? Recruitment and role modeling are likewise crucial for the navy, an integral part of training midshipmen, and also important for creating a functional work culture. The latter provides a strong argument for striking Maury's name from a building devoted to teaching at USNA, whose students include African Americans and other people of color who are not likely to be inspired by his example. Better role models are available for naming buildings and ships, including a number of African American ocean scientists (Zelnio, 2010; Baard, 2015; Baker, 2020; Hidayat and Bhatt, 2020). It is worth noting that women were also kept out of ocean science for longer than in many scientific fields. Responsible choice of role models can help with recruitment and retention.

The Mariner's Museum in Newport News, Virginia, provides a thoughtful example for dealing with Maury's legacy. Museum president Howard Hoege (2020) explained that the recent decision to remove Maury's name from the lake on museum grounds was prompted by imagining an African American student, exhilarated by the experience of doing science on the water, asking for whom the lake was named. "With one simple question, that young child's meaningful and experiential access to science and education is completely flipped... Maury's story is completely out of context for both the lake and how our visitors-not just this one child-will experience it." Hoege points out that this name change also respects the skilled African-American craftsmen who built the museum and lake in the 1930s. Maury is not being erased; he will continue to be presented in the museum's galleries, where his con- tradictions and racism can be represented alongside and, importantly, entangled with his naval reform, navigational contributions, and science.

Oceanographers who employ history in their teaching should reflect on the reasons why. Ideally, just as scientists strive to take their work beyond nationalist goals, so should the use of science's history transcend simplistic or nationalist origin stories. A textbook that explains that Maury "was vitally interested in the promotion of a maritime commerce" (Garrison and Ellis, 2015) might do well to elaborate that he "was vitally interested in the promotion of a maritime commerce dedicated to extending the institution of racial slavery from the US South to other parts of the world as an integral part of the expansion of American imperial power." Understanding that science in the past was connected to, emerged from, and contributed to politics, culture, and ideology puts scientists today in a better position to appreciate how their questions, and their funding, are shaped by present circumstances. Particularly in the post-Manhattan Project world, ethics has become an increasingly important part of science. Today, climate change provides an urgent framework for science, and historical perspective can helpful to clarify the extent to which the challenges scientists tackle are not simply technical but social and political as well. The example of Maury reveals an opportunity that is equally a responsibility: to remember and deploy ocean science history, starting with Maury's legacy but alert to other instances, without whitewashing. @

\section{REFERENCES}

Achbari, A. 2015. Building networks for science: Conflict and cooperation in nineteenth-century global marine studies. Isis 106(2):257-282, https://doi.org/10.1086/682020.

Baard, E. 2015. African Americans in marine science. Harbor Lab, February 5, https://harborlab.org/ 2015/02/05/african-americans-in-marine-sciences/. Baker, J. 2020. The black lives of marine biology. Marine Madness, June 19, https://marinemadness. blog/2020/06/19/the-black-lives-of-marine-biology/. Barbee, M. 2012. Matthew Fontaine Maury and the evolution of Southern memory. The Virginia Magazine of History and Biography 120(4):372-393. 
Blight, D.W. 2001. Race and Reunion: The Civil War in American Memory. Belknap Press of Harvard University Press, Cambridge, MA, 528 pp.

Burnett, D.G. 2005. Matthew Fontaine Maury's 'Sea of Fire': Hydrography, biogeography, and providence in the tropics. Pp. 113-134 in Tropical Visions in an Age of Empire. F. Driver and L. Martins, eds, University of Chicago Press, Chicago.

Caskie, J.A. 1928. Life and Letters of Matthew Fontaine Maury. Richmond Press, Richmond, VA, $191 \mathrm{pp}$.

Cole, D., and C. Duster. 2020. Richmond mayor invokes emergency powers to remove Confederate statues from city. CNN Politics, https://www.cnn.com/2020/07/01/politics/ richmond-stonewall-jackson-confederate-statuesremoved/.

Corbin, D.F.M., comp. 1888. A Life of Matthew Fontaine Maury. Sampson Low, Marston, Searle, \& Rivington, London, $326 \mathrm{pp}$.

Cox, K.L. 2019. Dixie's Daughters: The United Daughters of the Confederacy and the Preservation of Confederate Culture. New preface edition, University Press of Florida, Gainesville, $280 \mathrm{pp}$.

Deacon, M. 1997. Scientists and the Sea, 1650-1900: A Study of Marine Science, 2nd ed. Brookfield, VT, Ashgate, $551 \mathrm{pp}$.

Dick, S.J. 2003. Sky and Ocean Joined: The US Naval Observatory, 1830-2000. Cambridge University Press, Cambridge, UK, 609 pp.

Domby, A.H. 2020. The False Cause: Fraud, Fabrication, and White Supremacy in Confederate Memory. University of Virginia Press, Charlottesville, $272 \mathrm{pp}$.

Donegan, D. 2020. What to do about the Naval Academy's Confederate connections? Proceedings of the US Naval Institute, June 2020.

Garrison, T.S., and R. Ellis. 2015. Oceanography: An Invitation to Marine Science, 9th ed. Cengage Learning, Boston, 640 pp.

Grady, J. 2015. Matthew Fontaine Maury, Father of Oceanography: A Biography, 1806-1873. McFarland, Jefferson, NC, 353 pp.

Gregory, S. 2020. Maury High and two other Norfolk schools named for Confederates could be renamed. The Virginian-Pilot, June 17, https://www. pilotonline.com/news/education/vp-nwnorfolk-confederate-school-names-20200617gjvsizkbavesvc5g2y4e3rdhoy-story.html.

Hall, D. 1929. Armistice Day celebration to pay tribute to 'Pathfinder of the Seas.' Richmond TimesDispatch, November 10, pp. 1, 6 .

Hidayat, A., and E. Bhatt. 2020. Black History Month blog series 2020: Highlighting achievements of Black oceanographers. Woods Hole Oceanographic Institution blog, February 4, https://web.whoi.edu/big/black-history-month-blogseries-2020-highlighting-achievements-of-blackoceanographers/.

Hoege, H. 2020. The anatomy of a mission. The Mariners' Museum and Park Museum Blog, 29 June, https://blog.marinersmuseum.org/2020/ 06/the-anatomy-of-a-mission/.

Hardy, P.K. 2016a. Every ship a floating observatory: Matthew Fontaine Maury and the acquisition of knowledge at sea. Pp. 17-48 in Soundings and Crossings: Doing Science at Sea, 1800-1970. K. Anderson and H.M. Rozwadowski, eds., Science History Publications, Sagamore Beach, MA.

Hardy, P.K. 2016b. Matthew Fontaine Maury: Scientist. International Journal of Maritime History 28(2):402-410, https://doi.org/10.1177/ 0843871416637995.

Joachim, Z., and J. Alonso. 2020. Watch Now: Statue of Jefferson Davis torn down on Monument Avenue. Richmond Times-Dispatch, https://www.richmond.com/news/local/statue- of-jefferson-davis-torn-down-on-monumentavenue/article_64865aee-76bc-54e1-8e902fa749f8877b.html.

Johnson, W. 2013. River of Dark Dreams: Slavery and Empire in the Cotton Kingdom. Harvard University Press, Cambridge, MA, 526 pp.

Karp, M.J. 2011. Slavery and American sea power: The navalist impulse in the antebellum South. The Journal of Southern History 77(2):283-324.

Karp, M.J. 2016. This Vast Southern Empire: Slaveholders at the Helm of American Foreign Policy. Harvard University Press, Cambridge, MA, $350 \mathrm{pp}$

Lammons, G. n.d. Maury library is the ultimate source for naval oceanography. InfoDomain: Official Online Magazine of Naval Information Forces. https://www.public.navy.mil/fltfor/infodomain/ ArticleLibrary/art00076_MauryLibrary.aspx.

Leighly, J., ed. 1963. The Physical Geography of the Sea and Its Meteorology by Matthew Fontaine Maury. Belknap Press of Harvard University Press, Cambridge, MA, 432 pp.

Lewis, C.L. 1927. Matthew Fontaine Maury: The Pathfinder of the Seas. United States Naval Institute, Annapolis, 264 pp.

Majewski, J., and T.W. Wahlstrom. 2012. Geography as power: The political economy of Matthew Fontaine Maury. The Virginia Magazine of History and Biography 120(4):340-371.

Manning, T.G. 1988. US Coast Survey vs. Naval Hydrographic Office: A 19th-Century Rivalry in Science and Politics. The University of Alabama Press, Tuscaloosa, $202 \mathrm{pp}$.

Manzanares, K. 2020. Matthew Fontaine Maury statue removed on Richmond's Monument Avenue. WRIC ABC 8 News, https://www.wric.com/news/local-news/richmond/ maury-statue-in-richmond-will-be-removed/.

Marcus, A., and W. Woodward. 2020. "Monuments 'expire'-but offensive monuments can become powerful history lessons." The Conversation, Sept. 4, 2020, https://theconversation.com/ monuments-expire-but-offensive-monuments-canbecome-powerful-history-lessons-143318.

Maury, M.F. 1853. Explanations and Sailing Directions to Accompany the Wind and Current Charts, 5th ed. C. Alexander, Washington, DC, $492 \mathrm{pp}$.

Oceanography. n.d. Oxford English Dictionary Online.

Oreskes, N. 2020. Science on a Mission: How Military Funding Shaped What We Do and Don't Know about the Ocean. University of Chicago Press, Chicago, $744 \mathrm{pp}$.

Reidy, M.S., and H.M. Rozwadowski. 2014. The spaces in between: Science, ocean, empire. Isis 105(2):338-351, https://doi.org/10.1086/676571.

Reingold, N. 1964. Science in Nineteenth-Century America: A Documentary History. Hill and Wang, New York, 339 pp

Rozwadowski, H.M. 2005. Fathoming the Ocean: The Discovery and Exploration of the Deep Sea. Harvard University Press, Cambridge, MA, 292 pp.

Slotten, H.R. 1994. Patronage, Practice, and the Culture of American Science: Alexander Dallas Bache and the US Coast Survey. Cambridge University Press, Cambridge, UK, 228 pp.

Smith, J.W. 2018. To Master the Boundless Sea: The US Navy, the Marine Environment, and the Cartography of Empire. University of North Carolina Press, Chapel Hill, 280 pp.

Springston, R. 2019. Outdoor curiosities: Matthew Fontaine Maury statue. Richmond Times-Dispatch, August 11, 2019.

Stewart, R.H. 2008. Introduction to Physical Oceanography. Texas A\&M University, $345 \mathrm{pp}$.

Stommel, H. 1965. The Gulf Stream: A Physical and Dynamical Description, 2d ed. University of California Press, Berkeley, 248 pp.
Sverdrup, K.A., and E.V. Armbrust. 2008. An Introduction to the World's Oceans, 9th ed. McGraw-Hill Higher Education, New York, 508 pp. Varon, E.R. 2010. Disunion! The Coming of the American Civil War, 1789-1859. University of North Carolina Press, Chapel Hill, 472 pp.

Verney, M.A. 2020. “The Universal Yankee Nation”: Proslavery exploration in South America, 1850-1860. Diplomatic History 44(2):337-364, https://doi.org/10.1093/dh/dhz067.

Wahlstrom, T.W. 2015. The Southern Exodus to Mexico: Migration Across the Borderlands After the American Civil War. University of Nebraska Press, Lincoln, $189 \mathrm{pp}$.

Wayland, J.W. 1930. The Pathfinder of the Seas: The Life of Matthew Fontaine Maury. Garrett and Massie, Richmond, VA, 191 pp.

WHSV. 2020. JMU students challenge university to rename buildings named after Confederate leaders. WDBJ, June 9, https://www.wdbj7.com/ content/news/JMU-students-challengeuniversity-to-rename-buildings-named-afterConfederate-leaders-571139691.html?.

Witte, B. 2020. Naval Academy board chair calls to remove Confederate names from buildings. Navy Times, https://www.navytimes.com/news/yournavy/2020/06/11/naval-academy-board-chair-callsto-remove-confederate-names-from-buildings/.

Zelnio, K. 2010. Minorities in marine biology: The dearth of Black professors. Deep Sea News, October 1, http://www.deepseanews.com/2010/10/ minorities-in-marine-biology-the-dearth-of-blackprofessors/.

\section{ACKNOWLEDGMENTS}

The authors thank Michael Verney for providing Mary Blackford's letter. We are grateful for extensive and helpful comments from five anonymous reviewers.

\section{AUTHORS}

Penelope K. Hardy (phardy@uwlax.edu) is Assistant Professor, University of Wisconsin-La Crosse, La Crosse, WI, USA. Helen M. Rozwadowski (helen. rozwadowski@uconn.edu) is Professor, University of Connecticut, Avery Point, Groton, CT, USA.

\section{ARTICLE CITATION}

Hardy, P.K., and H.M. Rozwadowski. 2020.

Maury for modern times: Navigating a racist legacy in ocean science. Oceanography 33(3):10-15, https://doi.org/10.5670/oceanog.2020.302.

\section{COPYRICHT \& USAGE}

This is an open access article made available under the terms of the Creative Commons Attribution 4.0 International License (https://creativecommons.org/ licenses/by/4.0/), which permits use, sharing, adaptation, distribution, and reproduction in any medium or format as long as users cite the materials appropriately, provide a link to the Creative Commons license, and indicate the changes that were made to the original content. 